\title{
Climatic and glaciological information inferred from air-content measurements of a Law Dome (East Antarctica) ice core
}

\author{
Marc Delmotte, ${ }^{1,2}$ Dominique Raynaud, ${ }^{1}$ Vin Morgan, ${ }^{3}$ Jean Jouzel ${ }^{2}$ \\ ${ }^{1}$ Laboratoire de Glaciologie et Géophysique de l'Environnement du CNRS, BP 96, 38402 Saint-Martin-d'Ilères Cedex, France \\ ${ }^{2}$ Laboraloire des Sciences du Climat el de l'Environnement, UMR CEA-CNRS 1572, l'Orme des Merisiers CE Saclay, \\ 91191 Gif-sur-Yivette Cedex, France \\ ${ }^{3}$ Antartic CRC and Australian Antarclic Division, Box 252-80, Hobart, Tasmania 7001, Australia
}

\begin{abstract}
The total air content $(V)$ of ice has been measured along the Dome Summit South (DSS) core from Law Dome, East Antarctica. The main features of this record are the very well-preserved sub-annual fluctuations of $V$ (down to at least $900 \mathrm{~m}$ depth) and the significant increase of the $V$ values during the last deglaciation. The sub-annual variations reflect changes in close-off porosity, and we interpret the $V$ scasonal peaks as tracers of depth-hoar layers. For the longer time-scale, the large $V$ fluctuations observed are interpreted in terms of elevation and/or close-off porosity changes under different assumptions. We analyze the possible influence of a different global pressure field and/or a change in seasonal tcmperature and precipitation cycles during the last glacial period. Our cstimates of surface elevation changes derived from the $V$ data are then compared with independent reconstructions of past elevations.
\end{abstract}

\section{INTRODUCTION}

A knowledge of past ice-sheet elevation variations is important in the context of understanding climate-ice-sheet interactions and interpreting ice-core palaeo records. In particular, the interpretation of the isotope-ratio $\left(\delta^{18} \mathrm{O}\right.$ of ice) record in terms of temperature change requires an estimation of clcvation variations, because altitude changes have a direct impact on the temperature of a site, which is indistinguishable from that produced by climatic changes and therefore recorded by isotopes. In addition, improvement of past-climate simulations by atmospheric general circulation models (AGCMs) requircs a better knowledge of past ice-sheet topography. Information on the ice-sheet mass balance (and hence on sca-lcvel variations) is also obtained from elevation variations.

Ice-sheet models enable us to estimate past ice-sheet elevation variations in relation to climatic changes. However, most of these models are designed for large ice sheets where local conditions are relatively less significant, and they depend on boundary conditions such as accumulation, temperature and basal sliding, all of which are subject to uncertainties. They are therefore not well suited to the study of local variations, particularly local elevation change in a coastal area such as Law Dome, East Antarctica. An alternative way to derive information on ice-sheet elevation change is to measure the total amount of air entrapped in the bubbles of icc corcs. During the transformation of snow into ice, air at atmospheric pressure in the firn becomes progressively trapped as the open pores are transformed into closed bubbles in the icc (the close-off process). The air content $(V)$ of polar ice depends mainly on the atmospheric pressure and temperature prevailing at the formation site.
$V$ can be expressed in $\mathrm{cm}^{3} \mathrm{~g}^{1}$ of ice (Martinerie and others, 1992) as :

$$
V=V_{\mathrm{c}} \frac{P_{\mathrm{c}}}{T_{\mathrm{c}}} \frac{T_{0}}{P_{0}} .
$$

In Equation $(1), P_{\mathrm{c}}$ and $T_{\mathbf{c}}$ are the mean atmospheric pressure and the firn temperature at the elevation of the close-off level, $P_{0}$ and $T_{0}$ are the standard pressure $(1013 \mathrm{hPa})$ and temperature $(273 \mathrm{~K})$ and $V_{\mathrm{c}}$ is the pore volume at close-off $\left(\mathrm{cm}^{3} \mathrm{~g}^{-1}\right.$ of ice). Under present-day conditions, the spatial distribution of $V_{c}$ shows a clcar decreasc with decrcasing temperature. Martinerie and others (1992) used data from a large number of sites representing a wide range of climatic conditions (i.e. temperature, pressure and accumulation) to obtain a linear fit to the data of:

$$
V_{c}=\left(6.95 \times 10^{-4} T_{c}\right)-0.043 \quad R=0.90
$$

There is, however, considerable variability around the regression line (Fig. la), indicating that some of the $V_{c}$ fluctuations are not correlated with the close-off temperature.

Because of its pressure and elevation dependence (Fig. lb and c), air content measured in deep ice cores has previously been used as a palacobarometer, and past icc-shect elevations have been reconstructed from this information (Raynaud and Lorius, 1973, 1977; Budd and Morgan, 1977; Herron and Langway, 1987; Kameda, and others, 1990).

However, recent work conducted on the Vostok (East Antarctica) and GRIP (Greenland) cores (Martinerie and others, 1994; Raynaud and others, 1997) has revealed the complexity of the $V$ signal and the possibly major role of othcr metcorological and glaciological parameters such as wind-speed and atmospheric-pressure patterns (Martinerie and others, 1992, 1994; Raynaud and others, 1997). These 

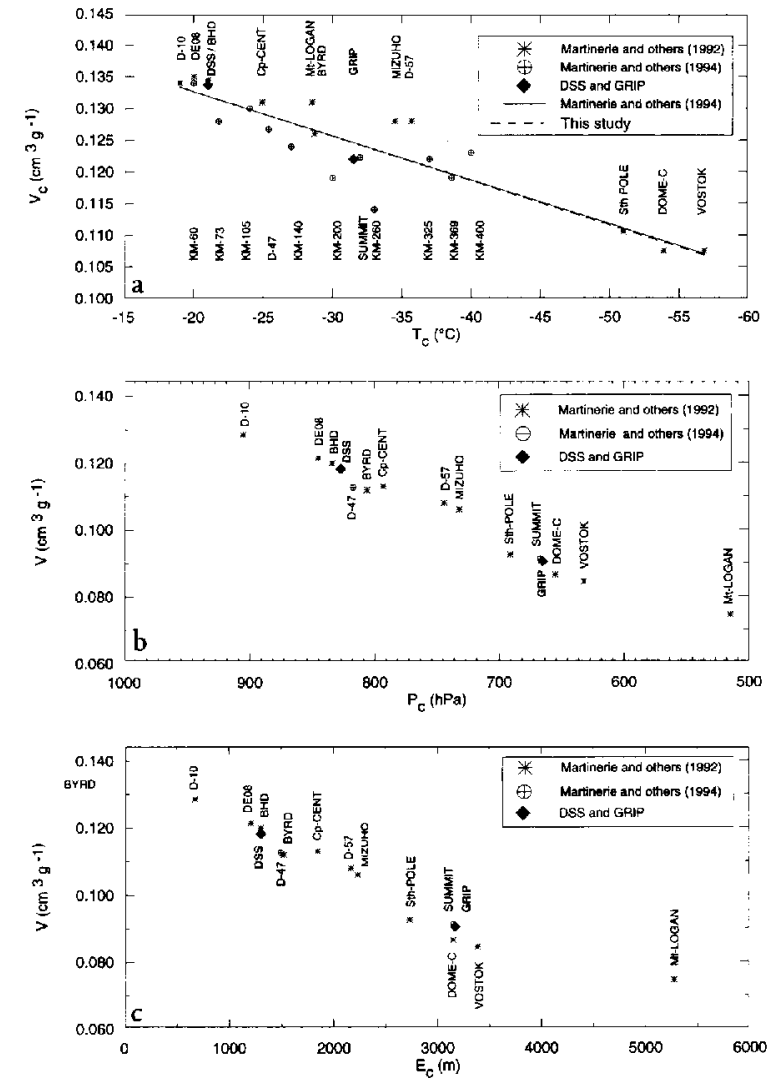

Fig. 1. Present-day distribution of $V$ and $V_{c}$ near the surface of Antartica and Greenland (adapted from Martinerie and others, 1992, 1994). The diamonds correspond to the two new sites of GRIP (Raynaud and others, 1997) and DSS (this work). (a) $V_{\mathrm{c}}=f\left(T_{\mathrm{c}}\right.$ ). Solid line represents linear regression oblained by Martinerie and others (1992); dotted line takes into account ( $R$ RIP and DSS sites. (b) V vs atmospheric pressure at close-off depth level. (c) $V$ is elevation of close-off level.

results also highlight the fact that variations in the porosity at close-off during past periods are not well constrained.

In this contcxt, we present here new air-content measurements obtained from the Dome Summit South (DSS) deep ice core from Law Dome. Law Dome $(200 \mathrm{~km}$ in diameter, $1390 \mathrm{~m}$ a.s.l.) is a small dome located in Wilkes Land on the coast of East Antarctica. Its ice flow is largely disconnected from that of the main East Antarctic ice shect, with a large saddle separating the two ice domains (Fig. 2b). The DSS site $\left(66^{\circ} 46^{\prime} \mathrm{S}, 112^{\circ} 48^{\prime} \mathrm{E} ; 1370 \mathrm{~m}\right.$ a.s.l.) is located $4.6 \mathrm{~km}$ southsoutheast of the dome summit and about $100 \mathrm{~km}$ from the East Antarctic margin (Fig. 2a). The site is of particular interest because the low temperatures (annual mean of $-22^{\circ} \mathrm{C}$ ) generally preserve the surface snow from summer melting, and the very large accumulation rate $0.7 \mathrm{~m} \mathrm{a}^{-1}$ ice equivalent) ensures that the DSS ice core provides very good temporal resolution for the recent part of the Holocene period (Morgan and others, 1997).

These characteristics allow us to investigate seasonal cycles of the air content during the late Holoccne period, and to propose a new interpretation involving atmospheric surface parameters and the snow structurc. We also show results for the last climatic transition and discuss these in terms of past changes of close-off porosity $\left(V_{\mathrm{c}}\right)$ and past ice-sheet elevation variation. Comparison with other indicators enables us to investigate the validity and the sensitivity of our different reconstructions.

\section{DSS $V$ MEASUREMENTS}

The results presented in this paper are based on more than 130 individual air-content measurements covering the full depth of the DSS core. Most of these were obtained using the barometric method described by Lipenkov and others (1995). This is based on accurate measurement of the pressure of air released in a calibrated cell after the melting and refreezing of an ice sample under controlled temperature conditions. An initial series of tests of the experimental system against a well-calibrated reference indicated an accuracy for the method of $\pm 0.6 \%$ (average reproducibility 土0.5\%; Lipenkov and others, 1995). During our study, we conducted two new series of measurements on a large number of samples, in order to further test the experimental system.

The first series consisted of the measurement of samples cut from the same slice of ice as was previously analyzed by the volumetric method, which consists of the collection of the air in the volumetric burette of a Toepler pump. The volumetric method has been tested and calibrated (including the use of cclls with calibrated volumc), and therefore provided an absolute reference for the $V$ measurcments with an accuracy of $\pm 1.5 \%$ (Raynaud and Whillans, 1982; Martinerie, 1990; Martinerie and others, 1992). Our new test results are presented in lable 1, together with the data already obtained by Lipenkov and others (1995). 'The average absolute difference between the barometric and volumctric methods is $1.07 \%$, which is in agrecment with the results of Lipenkov and others (1995). Taking into account all the double measurements available (i.e. our study and those of Lipenkov and others (1995), and considering a slightly different mode of calculation (sce Table l footnote), we determine an absolute accuracy of the barometric method of $\pm 0.9 \%$.

The second series of tests was used to evaluate the reproducibility by independent measurement of pairs of samples prepared from a single slice of ice. Most of the DSS samples have been checked by double measurement (Delmotte, 1997), particularly the ones corresponding to summer peaks (see section 3.2). The average reproducibility obtained from 50 double barometric measurements is $\pm 0.73 \%$.

Somc additional results, for the last climatic transition, were provided as a by-product of methanc-concentration measurements performed by a chromatographic method (Chappcllaz and others, 1997). The accuracy of this method does not excecd $\pm 5 \%$, but within this uncertainty the results obtained agree well with the barometric data, as shown in Figure 3.

All the results presented in this paper have been corrected for the cut-bubble effect. This correction arises from the gas lost from bubbles near the face of the samples, which are opened during sample cutting. Martinerie and others (1990) showed that for typical sample dimensions $(20-30 \mathrm{~g}$ of ice) this air loss can represent as much as $10 \%$ of the total. For the DSS core, the correction factor is $\sim 3.5 \%$ in the 200 $400 \mathrm{~m}$ depth interval, $\sim 1.84 \%$ in the $1100-1170 \mathrm{~m}$ depth interval and negligible below $1170 \mathrm{~m}$. The correction factor was calculated by a statistical method (Saltikov, 1976; Martincric, 1990; Martincric and others, 1990) from average bubble diameters measured on thin sections. Bubble diameters vary from $0.30 \mathrm{~mm}$ at $201 \mathrm{~m}$ depth to $0.20 \mathrm{~mm}$ at the bottom of the core $(1170 \mathrm{~m})$. 


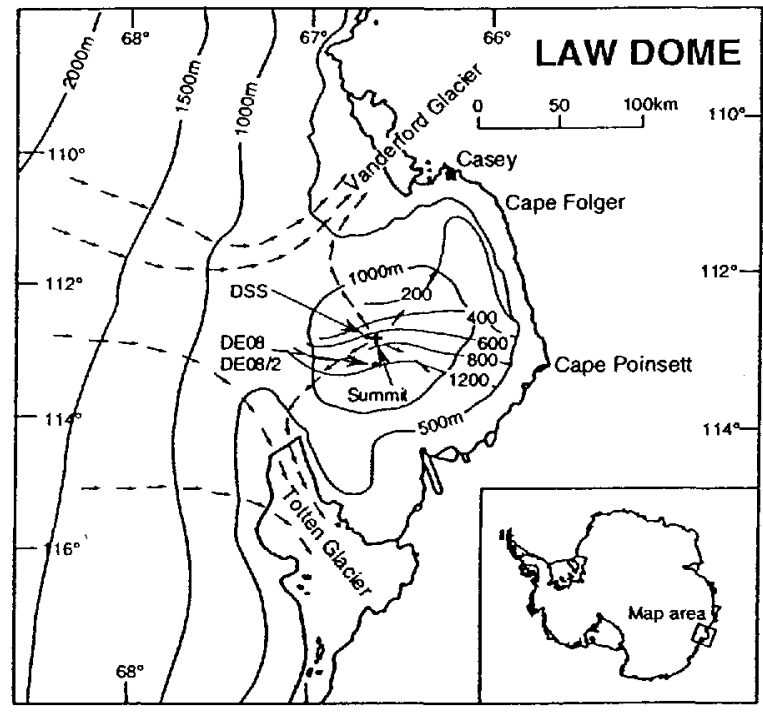

Law Dome

Elevation contours (m)

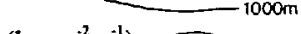

Accumulation rate contours $\left(\mathrm{kg} \mathrm{m}^{-2} \mathrm{a}^{-1}\right) \longrightarrow 400$ Ice f lowlines

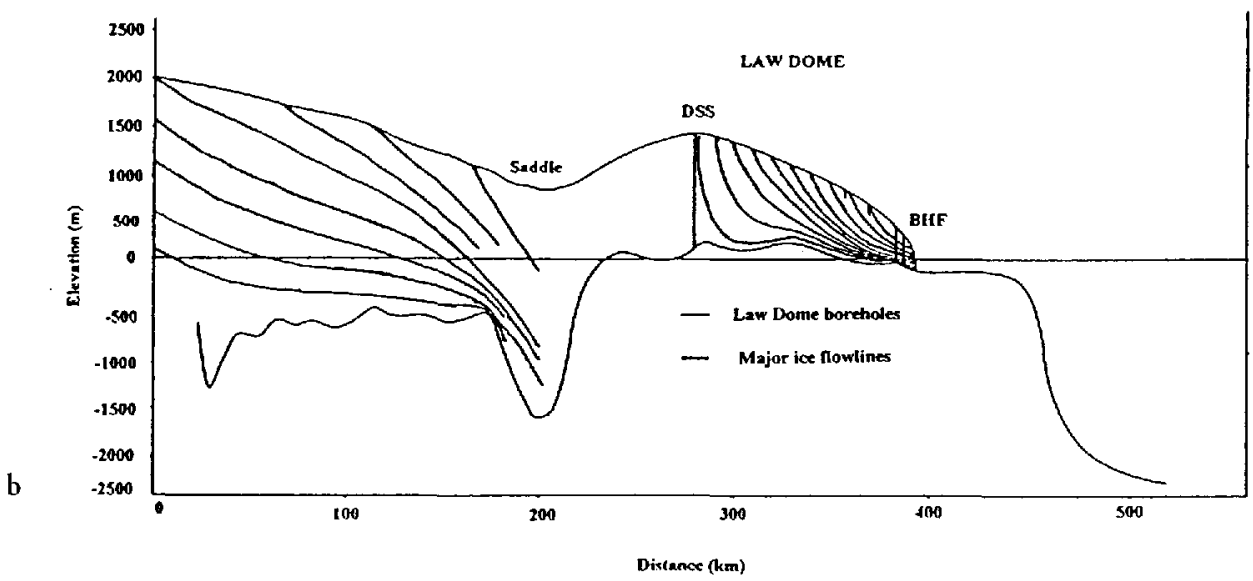

Fig. 2. Map location and characteristics of DSS coring site. (a) Geographical situation of Law Dome (adapted from Etheridge and others, 1996) (b) Iceflow of Law Dome, and large saddle existing between dome and main East Antarctic ice sheet (adapted from Budd and Morgan, 1977).

\section{THE LATE-HOLOGENE RECORD: LONG-TERM TREND AND SEASONAL VARIATIONS}

At DSS, the Holocene period is spread over the upper $1113 \mathrm{~m}$ of the core (Delmotte, 1997; Morgan and others, 1997). Over this depth interval we sampled at four levels: 200, 393, 591 and $903 \mathrm{~m}$ (corresponding ages of the icc arc $285 \pm 2$, $671 \pm 5,1220 \pm 10$ and $2955 \pm 150$ years before $\mathrm{AD} 1988$ ). At each depth level, we measured (at $3 \mathrm{~cm}$ resolution) continuous ice pieces $0.80-1 \mathrm{~m}$ long (except for the lowest level, where the length was only $0.26 \mathrm{~m}$ ). The data obtained enable us to investigate the long-term trend of the $V$ record, as well as the short-term (to sub-annual) variations.

\subsection{Late-Holocene $V$ trend}

The mean $V$ values calculated for each of the four depth levels corresponding to the late-Holocene period show no significant differences (Fig. 3), and lead to a $0.1182 \mathrm{~cm}^{3} \mathrm{~g}{ }^{1}$ average for the considered time period. The lack of a trend in $V$ reflccts the stability of the dome during the Holocene and supports the notion of a constant-size ice sheet as indicated by the stable-isotope $\left(\delta^{18} \mathrm{O}\right)$ record. Indeed, the smoothed $\delta^{18} \mathrm{O}$ record shown in Figure 3 exhibits fluctuations no larger than $1 \%$, which reflect temperature variations of $<2^{\circ} \mathrm{C}$. This corresponds to clevation change of $<150 \mathrm{~m}$, a variation which lies near the limit of uncertainty of our interpretation (see section 4).

The DSS late-Holocene mean $V$ value of $0.1182 \mathrm{~cm}^{3} \mathrm{~g}^{1}$ corresponds to a $V_{\mathrm{c}}$ value, calculated by Equation (1), of $0.133 \mathrm{~cm}^{3} \mathrm{~g}^{-1}$. Both this value and that for the GRIP site (Raynaud and others, 1997) lie close to the mean of the distribution of Martinerie and others (1994), as shown in Figure la. By adding these two new sites to the dataset of Martinerie and others (1994), and reconsidering the present-day relationship, we obtain the following linear relationship:

$$
V_{\mathrm{c}}=7.02 \times 10^{-4} T_{\mathrm{c}}(\mathrm{K})-0.045 \quad R=0.90 .
$$

We usc this new parameterisation, which includes the DSS and the GRIP data, in the following sections. It differs only slightly from the one previously established by Martinerie and others (1994) (scc Equation (2)).

\subsection{Sub-annual $V$ variations}

The high-resolution $V$ measurcments conducted at the four 
Table 1. Comparison of air-content measurements oblained using either the barometric or the volumetric method

\begin{tabular}{|c|c|c|c|c|c|c|c|c|c|}
\hline \multirow[t]{3}{*}{ Drilling site } & \multirow{3}{*}{$\begin{array}{c}\text { Depth of slice } \\
\text { m }\end{array}$} & \multirow{2}{*}{\multicolumn{2}{|c|}{$\begin{array}{c}\text { Volumetric method } \\
\qquad V_{v}\end{array}$}} & \multirow{2}{*}{\multicolumn{2}{|c|}{$\begin{array}{l}\text { Barometric method } \\
\qquad V_{b}^{c}\end{array}$}} & \multirow{4}{*}{$\begin{array}{c}\text { Average } \\
V^{*}=\frac{V_{*}+\eta_{1}}{2} \\
\mathrm{~cm}^{3} \mathrm{~g}^{-1} \\
\text { (7) }\end{array}$} & \multicolumn{2}{|c|}{ Difference betweeen two methods } & \multirow{4}{*}{$\begin{array}{l}\text { Source } \\
\text { (10) }\end{array}$} \\
\hline & & & & & & & \multirow{3}{*}{$\begin{array}{l}\frac{V_{x}-V_{L}}{V} \\
\% \\
\text { (g) }\end{array}$} & \multirow{3}{*}{$\begin{array}{c}\left|\frac{V_{x}-v_{z}}{V^{\alpha}}\right| \\
\% \\
\%\end{array}$} & \\
\hline & & $\begin{array}{l}\text { Measured value } \\
\mathrm{cm}^{3} \mathrm{~g}^{-1}\end{array}$ & $\begin{array}{l}\text { Mean zalue } \\
\mathrm{cm}^{3} \mathrm{~g}^{-1}\end{array}$ & $\begin{array}{l}\text { Measured zalue } \\
\mathrm{cm}^{3} \mathrm{~g}^{-1}\end{array}$ & $\begin{array}{l}\text { Mean value } \\
\mathrm{cm}^{3} \mathrm{~g}^{1}\end{array}$ & & & & \\
\hline (1) & (2) & (3) & (4) & (5) & (6) & & & & \\
\hline $\mathrm{Km} 100$ & 100.12 & 0.1163 & 0.1163 & $\begin{array}{l}0.1160 \\
0.1154\end{array}$ & 0.1157 & 0.1160 & 0.52 & 0.52 & 1 \\
\hline $\mathrm{Km} 100$ & 100.35 & 0.1162 & 0.1162 & $\begin{array}{l}0.1163 \\
0.1173\end{array}$ & 0.1168 & 0.1165 & -0.52 & 0.52 & 1 \\
\hline $\mathrm{Km} 100$ & 100.38 & 0.1151 & $0.115 \bar{l}$ & $\begin{array}{l}0.1140 \\
0.1157 \\
0.1164\end{array}$ & 0.1154 & 0.1152 & 0.23 & 0.23 & 1 \\
\hline $\mathrm{Km} 100$ & 100.41 & 0.1149 & 0.1149 & $\begin{array}{l}0.1164 \\
0.1164\end{array}$ & 0.1164 & $0.115 \overline{7}$ & 1.30 & 1.30 & 1 \\
\hline $\mathrm{Km} 100$ & 100.44 & 0.1150 & 0.1150 & $\begin{array}{l}0.1167 \\
0.1173\end{array}$ & 0.1170 & 0.1160 & -1.72 & 1.72 & 1 \\
\hline Km 100 & 100.47 & 0.1133 & 0.1133 & $\begin{array}{l}0.1133 \\
0.1131\end{array}$ & 0.1132 & 0.1133 & 0.09 & 0.09 & 1 \\
\hline $\mathrm{Km} 100$ & 100.5 .3 & $\begin{array}{l}0.1141 \\
0.1139\end{array}$ & 0.1140 & $\begin{array}{l}0.1133 \\
0.1156 \\
0.1145\end{array}$ & 0.114 .5 & 0.1142 & -0.41 & 0.41 & 1 \\
\hline $\mathrm{Km} 100$ & 100.56 & $0.1143^{\dagger}$ & 0.1143 & $\begin{array}{l}0.1146 \\
0.1147\end{array}$ & 0.1147 & 0.1145 & -0.31 & 0.31 & 2 \\
\hline Km 400 & 124.15 & $0.0895^{\dagger}$ & 0.0895 & 0.0913 & 0.0913 & 00904 & -2.05 & 2.05 & 2 \\
\hline $\mathrm{Km} 400$ & 124.29 & $\begin{array}{l}0.0912^{\dagger} \\
0.0901^{\dagger}\end{array}$ & 0.0907 & 0.0919 & 0.0919 & 0.0913 & -1.37 & 1.37 & 2 \\
\hline $\mathrm{Km} 400$ & 124.31 & 0.0931 & 0.0931 & $\begin{array}{l}0.0890 \\
0.090 .5\end{array}$ & 0.0898 & 0.0914 & (3.66) & (3.66) & I \\
\hline $\mathrm{Km} 400$ & 124.35 & 0.0888 & 0.0888 & $\begin{array}{l}0.0874 \\
0.0875\end{array}$ & 0.0874 & 0.0881 & 1.59 & $1 . \overline{5} 9$ & 1 \\
\hline $\operatorname{Km} 100$ & 124.58 & 0.0937 & 0.0937 & $\begin{array}{l}0.0932 \\
0.0944\end{array}$ & 0.0938 & 0.0938 & -0.11 & 0.11 & 1 \\
\hline $\mathrm{Km} 400$ & 124.67 & $0.0962^{\dagger}$ & 0.0962 & 0.0960 & 0.0960 & 0.0961 & 0.25 & 0.25 & 2 \\
\hline Vostok & 1937,40 & $0.0881^{\ddagger}$ & 0.0881 & 0.0897 & 0.0897 & 0.0889 & -1.80 & 1.80 & 2 \\
\hline Vostok & 1627.70 & $0.0845^{\ddagger}$ & 0.084 .5 & 0.0855 & 0.0855 & 0.0850 & -1.20 & 1.20 & 2 \\
\hline & & & & $\begin{array}{l}\text { Average } \\
\text { Standard devia } \\
\text { Global average } \\
\text { Standard devia }\end{array}$ & $\begin{array}{l}\text { on }(1 \sigma) \\
\text { without (366i) } \\
\text { on }(1 \sigma)\end{array}$ & & $\begin{array}{r}-0.31 \\
1.43 \\
-0.57 \\
1.00\end{array}$ & $\begin{array}{l}1.07 \\
0.97 \\
0.90 \\
0.70\end{array}$ & \\
\hline
\end{tabular}

Notes: The difference between the two methods has been calculated from a mean value corresponding to the average of the two methods for a given slice of ice isee column 8). In column 10, number 1 refers to the work of Lipenkov and others (1995), and number 2 to this study.

$\dagger$ Personal communication from V. Lipenkov (1996).

† Martineric $(1990)$.

depth levels reveal significant $V$ variations on a sub-annual time-scale. $\delta^{18} \mathrm{O}$ measured on the same samples clearly indicates the seasonality, with higher $\delta$ values corresponding to the summer, and lower values to the winter (Fig. 4). The records for the first three depth levels each contain two consecutive seasonal cycles. In addition, $\mathrm{H}_{2} \mathrm{O}_{2}$ concentration, another seasonal marker, was measured on the 201 and $393 \mathrm{~m}$ depth series. We observed that whereas the $\delta^{18} \mathrm{O}$ and $\mathrm{H}_{2} \mathrm{O}_{2}$ records show regular cycles with smooth transitions between summer and winter seasons, the $V$ signal is charactcrised by a relativcly constant background (around $0.117 \mathrm{~cm}^{3} \mathrm{~g}^{-1}$ ) intcrupted by short, sharp peaks $5-12 \%$ above the annual winter minimum and occurring within the summer period. The results are similar to other data from Law Dome (Lebel, 1978; Martinerie and others, 1992) and data from other locations such as Dyc 3 and Camp Century, Greenland Berncr, and others, 1978; Raynaud and Lebel, 1979; Raynaud and Whillans, 1982; Herron and Langway, 1987; Martinerie and others, 1992).
Since air-pressure fluctuations are smoothed by the slow diffusion of air in the firn, the seasonal variations in $V$ must be due to variations in close-off porosity. It has bcen proposed, for instance by Lebel (1978) and Raynaud and Whillans (1982), that seasonal variations of surface air temperature influence the snow porosity at the surface through the size and shape distribution of the firn grains, and that a memory of these initial seasonal fluctuations is maintained down to the close-off level.

On the other hand, using data from the very high-accumulation site DEO8 on Law Dome, Martinerie and others (1992) observed that the high $V$ (and hence $V_{c}$ ) peaks arc generally narrower than the summer isotopic $(\delta)$ peaks. These authors concluded that it is unlikely that the $V_{\mathrm{c}}$ scasonal changes are directly related to the surface air temperature and suggested instead that a sealing effect, as first proposed by Schwander and Stauffer (1984) and Stauffer and others $(1985)$, occurs in the close-off region. Dense winter layers close first, and thus prematurely scal the 


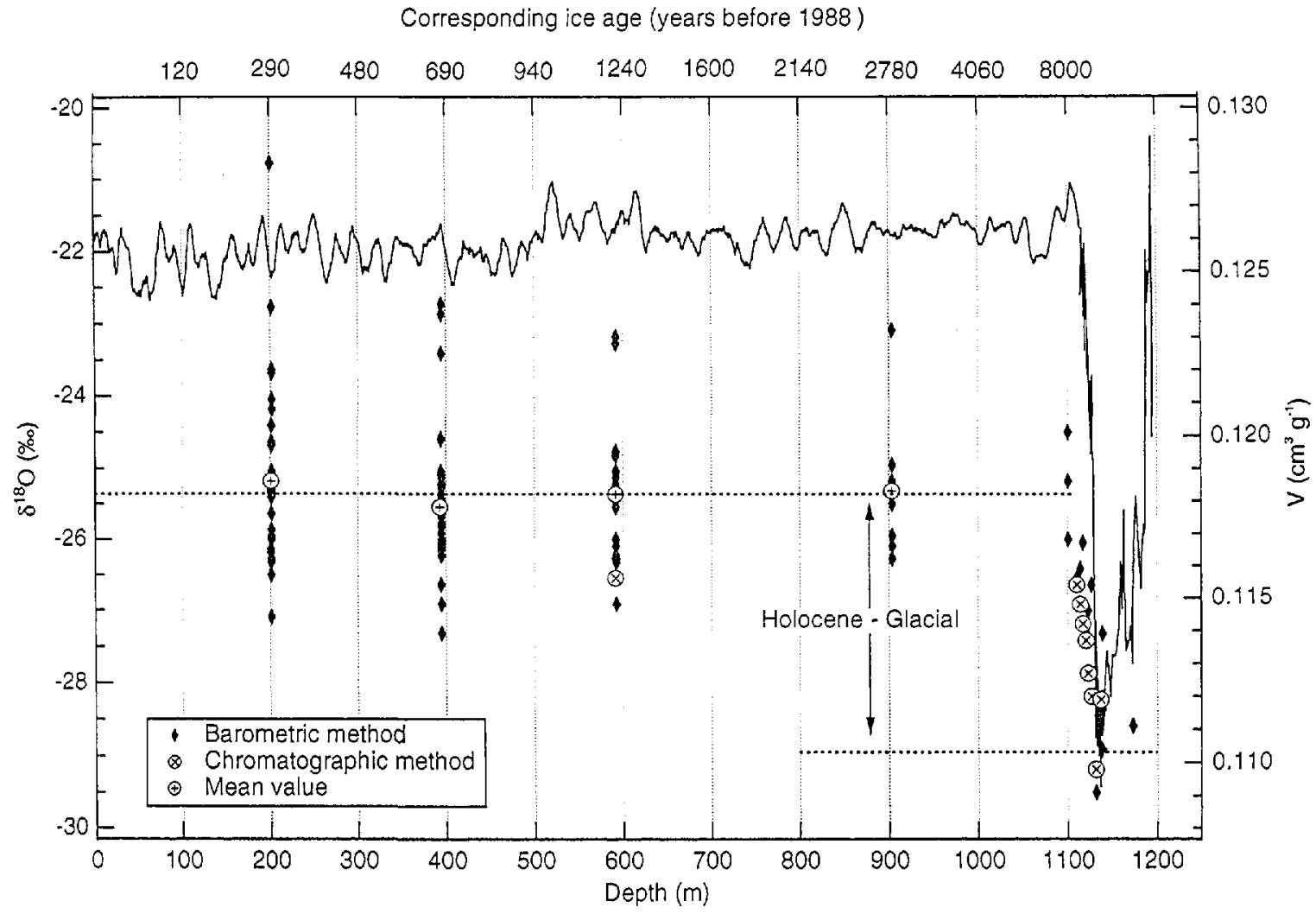

Fig. 3. DSS V records for the Holocene and the Last glacial-interglacial transition. Individual V measurements are represented as full diamonds, and open crossed circles are average zalues for each Holocene level. Dashed lines correspond to mean Holocene and glacial values (calculated from the four mean $V$ Holocene zalues and the glacial points). The isotopic record (adapted from Morgan and others, 1997), presenled as a smoothed curve for the Holocene parl, depicts the last climatic transition around $1113 \mathrm{~m}$ depth. Corresponding depth ice ages are indicated for the first 1100 m on upper axis. Belore that depth, no ages are indicated because the preliminary dating is not accurate enough.

summer layers found just below, which have a lower density (higher porosity).

We note that none of the above interpretations completely accounts for the typical narrowness of the $V$ peak.

Our high-resolution data provide new information for interpreting the $V$ seasonal records. We use the $\delta^{18} \mathrm{O}$ and $\mathrm{H}_{2} \mathrm{O}_{2}$ rccords to define precisely the timing of the $V$ peaks within the seasonal cycle. $\mathrm{H}_{2} \mathrm{O}_{2}$ concentrations depend principally on the intensity of solar radiation (Neftel and others, 1986, 1995), whereas isotopic maxima are associated with temperature maxima. Based on these two temporal indicators, Van Ommen and Morgan (1996) noticed a time lag ( $\sim 18$ days) between the maxima of peroxide concentration and the maxima of the isotopic composition measured in the ice of the DSS core. They linked the highest values of peroxide with the austral summer solstice. As a result, the isotopic maximum occurs around mid-January, in accordance with the temperature maximum from local meteorological data (Russell-Head and Simmonds, 1993). The $V$ peaks lag the isotopic maxima, and thus occur during the transition from summer to winter (Fig. 4). This period of the year is characterised by a strong temperature gradient in the upper $10 \mathrm{~m}$ of snow (Xie and others, 1989). The existence of such temperature gradients generally causes the formation of depth hoar, by sublimation of the water vapour from the warm lower layers to the cold uppcr layers (Alley, 1988; Alley and others, 1990; Paterson, 1994). Sublimation is restricted to the upper few meters of snow (i.e. it is sensitive to the surface meteorological conditions, , and its major conscquence is a modification of the structure of the snowpack. Depth-hoar layers are distinguished by coarse grains and low densities (Alley and others, 1990; Paterson, 1994), which rcsult in these layers being highly porous. We suggest that the late-summer peaks observed in $V$ are causcd by the preservation of the physical properties of the depth-hoar layers (specifically the narrow, low-density layer) down to the close-off depth. 'The peaks of high $V$ and therefore high $V_{c}$ are thus associated with high-porosity layers of depth hoar forming at or near the surface during the transition from summer to wintcr. This interpretation accounts for the narrow shape of the $V$ peaks in comparison with the isotope and $\mathrm{H}_{2} \mathrm{O}_{2}$ signal.

Depth-hoar layers have been identified in stratigraphic studies of several ice cores in the Law Dome area (Budd, 1966; Xie and others, 1989). Depth hoar could also play a role in other sites where seasonal $V$ variations have been reported (Lebcl, 1978; Raynaud and Lebel, 1979; Martinerie and others, 1992). At these sites the $V$ maxima are always associated with isotopically warm, i.e. summer, ice. Depthhoar formation generally occurs in autumn, but in some places temperature gradients within the snow pack are also sufficient in summer (Alley and others, 1990).

Other meteorological parameters, such as wind, may also play a role in determining the porosity of the surface snow and thus influence the close-off porosity (Martinerie and others, 1994; Raynaud and others, 1997). Alley (1988) reported on the formation and diagenesis of depth hoar in polar snow and firn and showed that depth-hoar layers were often associated with wind-slab formation. This accords with the correlation between wind speed and porosity, as pointed out by Martinerie and others (1994). Further information about the interpretation of the $V$ variations in relation to 

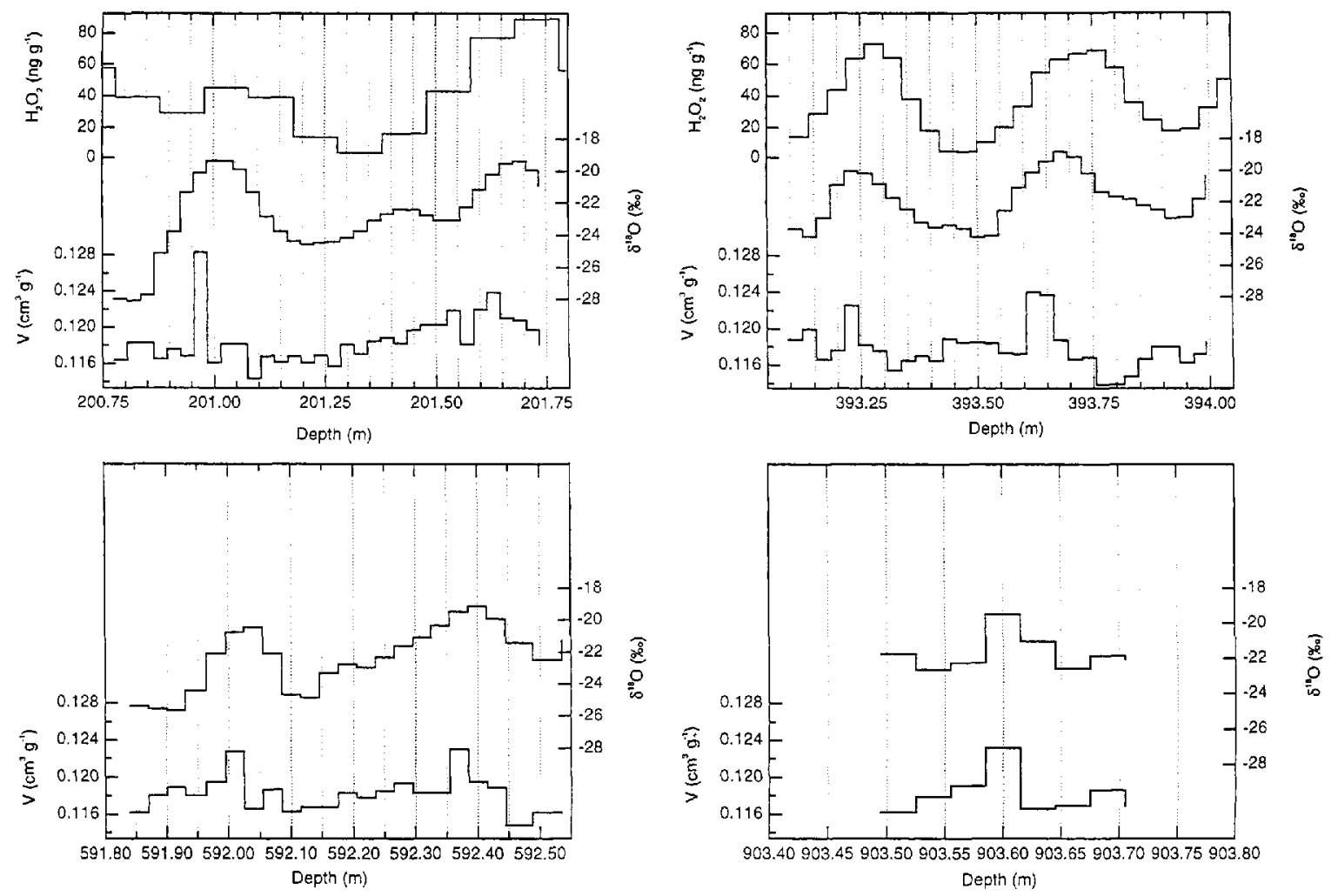

Fig. 4. Air-content sub-annual variations for the 200,393, 591 and $903 \mathrm{~m}$ depth levels. All the graphs are presented with isotope measurements performed on the same samples. The upper tweo graphs include the $\mathrm{H}_{2} \mathrm{O}_{2}$ record, which is also a seasonal marker.

snow and firn structure could be obtained from a combination of structure analyses and air-content measurements.

\section{AIR-CONTENT VARIATIONS OVER THE LAST GLACIAL-INTERGLACIAL TRANSITION: A RE- GORD OF PAST ICE-SHEET ELEVATION CHANGE?}

Because of the pressure dependence of $V$ (see Equation (1) and Fig. lb), air-content profiles have becn interpreted in terms of past icc-sheet elevation changes (Raynaud and Lorius, 1973; Raynaud and Lebel, 1979; Herron and Langway, 1987; Kameda and othcrs, 1990). Based on present-day $V_{\mathrm{c}}-T_{\mathrm{c}}$ parameterisations, and using the isotope profile as a record of past temperatures, these authors proposed past ice-sheet elevation reconstructions for different sites. Nevertheless, recent studies conducted on the Vostok (Martinerie and others, 1994) and GRIP (Raynaud and others, 1997) cores point out the complexity of the air-content signal. In Greenland, for example, past ice-sheet elevation reconstructions based on air-content data agree qualitatively with simulations produced by ice-sheet models (Raynaud and others, 1997), but obtaining quantitative estimates is not straightforward. Indeed, glacial-interglacial $V$ changes also reflect changes in the atmospheric pressurc pattern induced by large-scale atmospheric circulation changes at that time or during the glacial. Furthermore the mechanisms governing the present-day $V_{\mathrm{c}}$ variations are not fully understood, so $V_{c}$ behaviour under glacial conditions is not well constrained.

Hcre, we first investigate the glacial-interglacial $V$ change in terms of pressure and clevation changes, assuming that the present-day $V_{\mathrm{c}}-T_{\mathrm{c}}$ relationship (Equation (3)) is valid for the past periods and using the ice isotopic record as a temperature indicator. We then discuss the reliability of our results and the possible influence of other parameters.
We finally propose a range of surface-clevation change deduced from air-content data and compare it with other independent elevation reconstructions.

\subsection{The DSS record}

By combining all our barometric and chromatographic aircontent measurements between 1100 and $1140 \mathrm{~m}$ depth (2l different lcvels) we obtain a $V$ record of the transition from the Last glacial to the Holocene. The results show a gradual incrcasc of the air content, from typical Last glacial values around $0.110 \mathrm{~cm}^{3} \mathrm{~g}^{-1}$ to the mean Holocene valuc of $0.118 \mathrm{~cm}^{3} \mathrm{~g}^{-1}$ (Fig. 3). The $V$ increase parallels the isotope record, but the scatter over the limited number of measurements during the deglaciation and the lack of $V$ measurements for the carly Holocene period (Fig. 3) preclude investigation of any precise timing difference. According to Whillans (1981), the early Holocene should be the critical period when focusing on the time response of an ice sheet to an accumulation and/or temperature increase.

The scasonal fluctuations of $512 \%$ observed in the Holocene $V$ data are not seen in the transition record because, at this depth, as a result of layer thinning, the samples cover a much longer time period than for the Holocene samples. For instance, at $1100 \mathrm{~m}$ depth a $3 \mathrm{~cm}$ sample represents at lcast 3 years' accumulation. The $7 \%$ increase in $V$ between the glacial and the Holocene therefore represents a long-term change in air content duc to change in air pressure and close-off volume $\left(V_{\mathrm{c}}\right)$.

\subsection{Law Dome past ice-sheet elevation variations}

We first assume that Equation (3), linking the porosity at close-off with the temperature at close-off, remains valid during glacial conditions. We test the sensitivity of the reconstructed elevations by applying different $\delta-T$ relationships. Firstly (Tablc 2, case 1), we cstimate the close-off temperature 
Table 2. Law Dome past ice-sheet elevation variation inferred from air-conlent measurements.

\begin{tabular}{|c|c|c|c|c|c|c|c|c|}
\hline \multirow[t]{3}{*}{$\begin{array}{l}\text { Sensitivity } \\
\text { experiment }\end{array}$} & $\begin{array}{c}V \\
\text { measured }\end{array}$ & $\begin{array}{l}\text { Temperature }\left(T_{c}\right) \\
\text { (calculated using isotopic } \\
\text { transfer function) }\end{array}$ & $\begin{array}{l}\text { Pare volume }\left(V_{c}\right) \\
\text { (calculated using } \\
\text { Equation (3)) }\end{array}$ & $\begin{array}{l}\left.\text { Pressure ( } P_{0}\right) \\
\text { (calculated using } \\
\text { Equation (1) })\end{array}$ & $\Delta P$ & $\begin{array}{l}\text { Glacial } \\
\text { corrected }\end{array}$ & ient day & corrected \\
\hline & $\mathrm{cm}^{3} \mathrm{~g}^{1}$ & $\mathrm{~K}$ & $\mathrm{~cm}^{3} \mathrm{~g}^{-1}$ & mbar & mbar & mibar & $\mathrm{m}$ & $\mathrm{m}$ \\
\hline & (1) & (2) & (3) & (4) & (0) & (6) & (7) & (8) \\
\hline Present day & 0.1182 & $251^{*}$ & $\begin{array}{l}0.1331^{\dagger} \\
0.1312\end{array}$ & $\begin{array}{l}827^{*} \\
839\end{array}$ & & & & \\
\hline $\begin{array}{l}\text { Last Glacial Period, } \\
\text { case } 1\end{array}$ & 0.1103 & 240 & 0.1235 & 795 & $\begin{array}{r}-32 \\
44\end{array}$ & $\begin{array}{r}22 \\
-34\end{array}$ & $\begin{array}{l}291 \\
400\end{array}$ & $\begin{array}{l}200 \\
309\end{array}$ \\
\hline $\begin{array}{l}\text { Last Glacial Period, } \\
\text { case } 2\end{array}$ & 0.1103 & 235 & 0.1200 & 802 & $\begin{array}{r}-25 \\
37\end{array}$ & $\begin{array}{l}-15 \\
-27\end{array}$ & $\begin{array}{l}227 \\
336\end{array}$ & $\begin{array}{l}136 \\
245\end{array}$ \\
\hline $\begin{array}{l}\text { Last Glacial Period, } \\
\text { case } 3\end{array}$ & 0.1103 & 235 & 0.1235 & 779 & $\begin{array}{l}-48 \\
-60\end{array}$ & $\begin{array}{l}-38 \\
-50\end{array}$ & $\begin{array}{l}436 \\
\mathbf{5} 45\end{array}$ & $\begin{array}{l}345 \\
455\end{array}$ \\
\hline
\end{tabular}

Notes: Sensitivity of the reconstruction to different parameterisations: case $\mathrm{l}$ : classical interpretation of the $V$ signal using spatial isotopic gradient $0.65 \%$. ${ }^{1}$ to calculate the temperature used in both Fquations (1) and (3); case 2. same as for case l, but using scasonal isotopic approach (0.44\% " $\mathrm{C}^{-1}$ ) instead of spatial gradient; case 3: seasonal isotopic parameterisation was used to infer the $T_{c}$ temperature in Equation (1), and spatial gradient was used to describe the temperature in the $V_{\odot} T_{c}$ relationship (Equation (3)). The corresponding elevation changes are calculated using the present-day pressure elevation gradient of $-0.11 \mathrm{mbar} \mathrm{m}^{-1}$ (as given by Martinerie, 1990). In each case, two calculations have been made, the first using the present-day pressure (827 mbar), the scrond using the calculated pressure given by Equation (1) (839 mbar). 'l'his provides us with boundary limits, which can be considered as error bars for our estimations.

* Present-day value.

Cialculated using Equation (1) and present-day automatic weather station pressure for comparison with parametcrisation mothod.

in the glacial using the classical $\delta-T$ transfer function, i.e. spatial gradicnt of $0.65 \%{ }^{\circ} \mathrm{C}^{-1}$ given by Morgan (1979), and secondly (Table 2, case 2), we use the seasonal gradient of $0.44 \%{ }^{\circ} \mathrm{C}^{-1}$ (Van Ommen and Morgan, 1997). In doing so we implicitly assume that the true transfer function lics somewhere between these two values, this choice allowing us to brackct the clevation change between an upper and a lower bound. (A detailed discussion of the validity of the isotope/tempcrature transfer function, beyond the scope of this paper, can be found in Jouzel and others (1997).) The difference in glacial/interglacial elevation change obtained for the two cases is $\sim 50 \mathrm{~m}$ (see Table 2), i.c. the clevation change is not very sensitive to a single temperature change.

Results obtained along the vostok dud GRIP cores (Martinerie and others, 1994; Raynaud and others, 1997) strongly suggest that a simple use of the $V_{c}-T_{c}$ relationship alone cannot cxplain the long-term $V$ fluctuations. Indecd, other climatic parameters such as changes in wind speed (Martinerie and othcrs, 1994) or in the seasonality of the precipitation (Raynaud and others, 1997) may affect the firn porosity. At DSS the mean wind speed is fairly constant all year round at $8.3 \mathrm{~m} \mathrm{~s}^{-1}$. This lies above the threshold of $6.0 \mathrm{~m} \mathrm{~s}^{-1}$ given by Martinerie and others (1994) for significant wind snowpacking, which can have a significant effect on the surface snow density (e.g. snow porosity; Kotlyakov, 1961). Therefore we cannot exclude the possibility that some of the $V_{\mathrm{c}}$ variations in the past are related to changes in the wind.

Recently, new interest has been shown in possible changes in the seasonality of the temperature and/or precipitation during the last Glacial Period. Simulations conducted with several AGGMs (unpublished information from G. Krinner and others) show increased amplitudes of the annual temperature cycles during the Last Glacial Maximum (LGM), mainly due to colder temperature in winter than in summer. Such seasonal changes would lcad to stronger summer-to-winter temperature gradients, which in turn could influence the formation of depth hoar. As a result, more intensc depth-hoar layers should occur, which should be reflected by wider and/or higher $V$ peaks. We can investigate the effect of a temperature seasonality change using our Holoccne sub-scasonal data. For example, if we suppose a doubling or tripling of the late-summer peak duration during the Glacial Period at DSS, this would increase the mean annual $V$ signal by a maximum of $1 \%$ or $1.8 \%$, respectively (sce Table 3). On the other hand, if we consider not only a change in the peak duration but also a $15 \%$ change in the peak amplitude (induced by a $15 \%$ increase in the temperature seasonal-cycle amplitude as suggested by AGCM simulations; personal communication from $\mathrm{G}$. Krinner, 1997) this leads to a maximum $V\left(V_{c}\right)$ change of $2.1 \%$ (Table 3 ). Such a change is small compared to the glacial interglacial $V$ increase $(7 \%)$ and would lead to higher $V\left(V_{\mathrm{c}}\right)$ during the deglaciation. On the other hand, sublimation processes involved in depth-hoar formation are sensitive not only to temperature gradients but also to the temperature itself. If we assume only that the surface temperature was lower during the ice age, then the depth-hoar formation would be reduced. Our calculations in Table 3 do not include such an effect. It is possible that a seasonality change in the temperature cycle could be completely counterbalanced by the temperature decrease during the LGM, leading to similar or even lower $V\left(V_{c}\right)$ values.

Another way to investigate the influence of non-thermal parameters (e.g. wind and/or seasonality changes) on the $V$ variations is to use the spatial gradient to describe the temperature in Equation (3), and the seasonal gradient in Equation (1) to calculate $P_{c}$ (Table 2, case 3 ). This approach is justified becausc $V_{\mathrm{c}}$ should be more sensitive to climatic conditions occurring when the snow is deposited (cf. section 3.2), whereas the close-off temperature, which is the temperature shown in the denominator of Equation (1), reflects the mean interannual temperature at the sice. We assume that the spa- 
Table 3. Effect of seasonality change on air-content fluctuations

\begin{tabular}{|c|c|c|c|c|c|c|c|c|}
\hline & \multirow[t]{2}{*}{ Winter } & \multirow[t]{2}{*}{$\begin{array}{l}\text { Mean V } \\
\text { (fullyear) }\end{array}$} & \multirow{2}{*}{$\begin{array}{c}\text { Summer } \\
\text { amplitude } \\
\text { change }\end{array}$} & \multirow[t]{2}{*}{$\begin{array}{l}V \text { summer } \\
\text { value }\end{array}$} & \multicolumn{2}{|c|}{$\begin{array}{l}\text { Double summer-duration } \\
\text { calculated mean } V\end{array}$} & \multicolumn{2}{|c|}{$\begin{array}{l}\text { Triple summer-duration } \\
\text { calculated mean } V\end{array}$} \\
\hline & & & & & Value & $\begin{array}{l}\text { Variation from } \\
\text { present-day value }\end{array}$ & Value & $\begin{array}{l}\text { Voriation from } \\
\text { present-day value }\end{array}$ \\
\hline & $\mathrm{cm}^{3} \mathrm{~g}^{-1}$ & $\mathrm{~cm}^{3} \mathrm{~g}^{-1}$ & $\%$ & $\mathrm{~cm}^{3} \mathrm{~g}^{-1}$ & $\mathrm{~cm}^{3} \mathrm{~g}^{-1}$ & $\%$ & $\mathrm{~cm}^{3} \mathrm{~g}^{-1}$ & $\%$ \\
\hline & (1) & (2) & (3) & (4) & (3) & (6) & (7) & $(8)$ \\
\hline Max. & & & 0 & 0.1283 & 0.1194 & 1.00 & 0.1203 & 1.76 \\
\hline Mean & 0.1176 & 0.1182 & ) & 0.1232 & 0.1185 & 0.28 & 0.1190 & 0.68 \\
\hline Min. & & & 0 & 0.1225 & 0.1184 & 0.18 & 0.1188 & 0.53 \\
\hline Max. & & & 15 & 0.1299 & 0.1197 & 1.23 & 0.1207 & 2.09 \\
\hline Mcan & 0.1176 & 0.1182 & 15 & 0.1240 & 0.1187 & 0.40 & 0.1192 & 0.85 \\
\hline Min. & & & 15 & 0.1232 & 0.1185 & 0.29 & 0.1190 & 0.68 \\
\hline
\end{tabular}

Rites: We have considered two hypotheses. No change in the $V$ summer peak amplitude and a $15 \%$ amplitude change. For each hypothesis, we also consider threc different cases corresponding to the maximum, the mean and the mimimum amplitude cncountercd in the $V$ scasonal data sce Fig. 4 . Columns 5 and 7 present the mean $V$ change assuming a doubling and tripling, respectively, of the summer-peak duration and assuming no change in the winter mean (column 1) Columns 6 and 8 express these changes in terms of percentage variation with respect to the present-day $V$ mean value (column 2 ).

tial isotopic gradicnt probably better reflects the tempcrature conditions prevailing during the snow deposition, whereas the seasonal isotopic gradient is a better approximation of the mean surfacc interannual temperature.

The results of the different sensitivity tests are summarised in lable 2. All threc cases predict a lower pressure (higher elevation) on the Law Dome during the last Glacial Period (Table 2), but they lead to pressure and elevation variations of -25 to $-48 \mathrm{mbar}(+227$ to $+436 \mathrm{~m})$, respectively, with reference to the present-day pressure of $827 \mathrm{mbar}$ (and using the current local pressure-clcvation gradient, - 11 mbar $\left(100 \mathrm{~m}^{-1}\right.$ (Martinerie, 1990)).

Part of the pressure variation could result from changes in the atmospheric pressure field during the LGM. Recent investigations on the LGM pressure changes have been conducted by G. Krinner and others (unpublished information), using scveral AGCMs. Most of the models agree on a lowering of the pressure field over Antarctica in the range 0 15 mbar during the LGM, depending on the elevation of the considered site. In the case of DSS ( $1370 \mathrm{~m}$ a.s.l.), the pressurc lowering should have been on the order of 5-15 mbar. Assuming a mean pressure decrease of 10 mbar during the LGM, we infer a thinning of $135-345 \mathrm{~m}$ for the summit region of Law Dome between the LGM and the Holocenc.

In summary, our $V$ data indicate that during the last deglaciation the summit region of Law Dome was subject to a maximum lowering of $135-345 \mathrm{~m}$. The large range is mainly linked with uncertainty in the behaviour of the close-off porosity. These estimates do not include any effect of less prominent depth-hoar development due to colder temperatures during the glacial.

\subsection{Comparison with other elevation indicators at Law Dome}

Past ice-sheet elevation changes can also be estimated by ice-sheet modelling or glaciological and/or geomorphologic indicators. No detailed modelling reconstruction has yet been dedicated to the specific region of Law Dome (largescale Antarctic models do not properly represent Law Dome as a single dome because of their grid resolution). On the other hand, estimates of glacial-interglacial elevation changes deduced from isotopic records measured in the Law Dome coastal arca (Grootes and Stuiver, 1987) and geomorphologic studies in the vicinity of this site (Goodwin, 1995) are available for the last climatic transition. Both of these studies predict a thinning of a few hundred metres during the deglaciation, and confirm that the dome retained ice flow independent of the main East Antarctic ice sheet during the LGM and was not overridden by the East Antarctic major ice sheet, as previously suggested by Budd and Morgan (1977). Note that the elevation-change estimate given by the isotopic record of the BHF core (Grootes and Stuiver, 1987) is not very accurate for the summit area bccause BHF is locatcd near the ice-shcct margin and its isotopic record includes a significant variation due to ice advection (Fig. 2b). In contrast to this marginal ice core, the DSS record is only minimally affectcd by changes in the origin of the ice. In DSS the glacial-interglacial $\delta$ shift is $7 \%$. Isotopic records from inland in East Antarctica, where elevation changes are expected to be small due to the very low accumulation, indicate lower shifts: $6.0 \%$ at Vostok (Jouzel and others, 1987), 5.4\%o at Dome C (Lorius and others, 1979) and 5.8\% at Dome B (Jouzel and others, 1995). If we assume that the isotopic shifts of Dome C, Dome B and Vostok are representative of a pure climatic change, the average difference from DSS, $1.3 \%$, can be attributed to an elevation effect. With the present-day local isotopc-clcvation gradient of $0.5 \%$ (100 m) $)^{-1}$ (Budd and Morgan, 1977), this leads to an elevation decrease of about $260 \mathrm{~m}$.

All these estimates are on the whole in very good agreement with our reconstruction based on $V$ data.

\section{CONCLUSIONS}

Understanding seasonal variations in the air content $(V)$ of polar ice is important for investigating the climatic factors influencing the changes of $V$ on long time-scales (e.g. glacial-interglacial cycle). The high-resolution $V$ measurements performed on parts of the late-Holocene ice of the DSS core reveal narrow $V$ peaks in the part of the core deposited in the late summer. Wc propose that these peaks are due to low-density layers of firn produced by depth hoar formed at or near the surfacc.

For the Last glacial-interglacial transition, our results indicate a maximum lowering of the surface at Summit of $136-345 \mathrm{~m}$. The main uncertainty about the elcvation is due 
to the poorly constrained behaviour of the porosity at closeoff. This includes the influence of depth-hoar formation during glacial times. This small altitude variation is in agreement with other indicators of elevation changes and suggests that the general shape of Law Dome remained essentially similar during the Glacial Period and the Holocene.

\section{ACKNOWLEDGEMENTS}

The thesis grant of M.D. was supported by the Commissariat à l'Energie $\Lambda$ tomique (INSTN). We acknowlcdge the support of the Programme National d'Étude de la Dynamique du Climat. We thank J. Chappellaz for providing the chromatographic measurements, and P. Martincric, J.-M. Barnola and $\mathrm{G}$. Krinner for fruitful discussions. We also thank the members of the Australian National Antarctic Research Expeditions who worked tirelessly to retrieve the icc corc. We are indebted to the two anonymous reviewers for their helpful remarks and comments.

\section{REFERENGES}

Alley, R. B. 1988. Concerning the deposition and diagenesis of strata in polar firn. J. Glaciol., 34(118), 283-290.

Alley, R. B., E. S. Saltzman, K. M. Culfey and J.J. Fitzpatrick. 1990. Summertime formation of depth hoar in central Greenland. Geophys. Res. Lett., $17(12), 2393-2396$.

Berner, W., B. Stauffer and H. Oeschger. 1978. Past atmospheric composition and climate, gas parameters measured in ice cores. Nature,

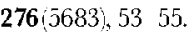

Budd, W. F. 1966. Glaciological studies in the region of Wilkes, castern Antartica, 196]. ANARE Sci. Rep., Ser. A (IV). Glaciol 88

Budd, W. F. and V. I. Morgan. 1977. Isotopes, climate and ice sheet dynamics from core studies on Law Dome, Antarctica. International Association of Hydrological Sciences Publication 118 (Symposium at Grenoble 1975 Isotopes and Impurities in Snow and Ice), 312-321.

Chappellaz, J. and 7 others. 1997. Changes in the atmospheric $\mathrm{CH}_{4}$ gradient between Greenland and Antarctica during the Holocenc. 7. Geophys. Res., 102 ( Dl3), 15,987-15,997

Delmotte, M. 1997. Enregistrements climatiques à Law Dome: variabilité pour les périodes récentes et pour la déglaciation. (Thèse de doctorat de troisième cycle, Université Joseph Fourier-Grenoble I.;

Etheridge, D. M., I. P. Steclc, R. L. Langenfelds, R. J. Francey, J-M. Barnola and V. I. Morgan. 1996. Natural and anthropogenic changes in atmospheric $\mathrm{CO}_{2}$ over the last 1000 years from air in Antarctic ice and firn. 7. Geophys. Res., 101 (D2), 411.5-4128.

Goodwin, I. D. 1995. On the Antarctic contribution to Holocene sea-level. (Ph.D. thesis, University of Tasmania.

Grootes, P. M. and M. Stuiver. 1987. Ice sheet elevation changes from isotope profiles. International Association of Hydrological Sciences Publication 170 Symposium at Vancouver 1987 - The Physical Basis of Ice Sheet Modelling, 269-281.

Herron, S. L. and C. C. Langway, Jr. 1987. Derivation of paleoclevations from total air content of two deep Greenland ice cores. International Association of Hydrological Sciences Publication 170 (Symposium at Vancouver 1987 - The Physical Basis of Ice Sheet Modelling), 283-295.

Jouzel, J. and 6 others. 1987. Vostok ice corc: a continuous isotope temperature record over the last climatic cycle $\{160,000$ years $)$. Nature, $329(6138), 403-408$.

Jouzel, J. and II others. 1995. The two-step shape and timing of the last deglaciation. Climate Dyn., $11(3), 15 \mathrm{l}-161$.

Jouzel, J. and 12 athers. 1997. On the validity of the temperature reconstruction from water isotopes in ice cores. 7 . Geophys. Res., 102(C12;, 26,471$26,487$.

Kameda, T., M. Nakawo, S. Mae, O. Watanabe and R. Naruse. 1990. Thinning of the ice sheet estimated from total gas content of ice cores in $\mathrm{Mi}$ zuho Plateau, East Antarctica. Ann. Glaciol., 14, 131-135.
Kotlyakov, V. M. 1961. Snezhnyy pokrov Antarktidy i ego rol' v sovremennom oledencnii materika [Snow cover in the Antarctic and its role in modern glaciation of the continent]. Akad. Nauk SSSR, Mezhd. Kom., Ser. IX. Razdel Programmy MGG (Glyatsiologiya) 7

Lebel, B. 1978. Porosité et teneur en gaz de la glace polaire récente: applications à létude des carottes prólevées en profondeur. (Thèse de doctorat de troisième cycle, Université Scientifique et Médicale de Grenoble.)

Lipenkov, V., F. Candaudap, J. Ravoire, E. Dulac and D. Raynaud. 1995. A new device for the measurement of air content in polar icc. 7 . Glaciol. $41(138), 423-429$.

Lorius, G., L. Merlivat, J. Jouzel and M. Pourchet. 1979. A 30,000-yr isotope climatic record from Antarclic ice. Nature, 280 (5724), 644-648.

Martinerie, P. 1990. Teneur en gaz des glaces polaires. Variations géographiques actuelles, variations au cours du dernicr cycle climatique dans la région de Vostok. (Thèse de doctorat, Université Joseph Fourier Grenoble I.

Martinerie, P., V.Ya. Lipenkov and D. Raynaud. 1990. Correction of aircontent measurements in polar ice for the effect of cut bubbles at the sur face of the sample. 7. Glaciol. 36(124), 299-303.

Martinerie, P., D. Raynaud, D. M. Etheridge, J.-M. Barnola and D. Mazaudier. 1992. Physical and climatic parameters which influence the air content of polar ice. Earth Planet. Sci. Lett., 112(1-4), 1-13.

Martincric, P., V.Ya. I ipcnkov, D. Raynaud, J. Chappellaz, N. I. Barkov and C. Lorius. 1994. Air content paleo record in the Vostok ice cor (Antarctica): a mixed record of climatic and glaciological parameters. 7. Geophys. Res., 99 (D5), 10,565-10,576.

Morgan, V. 1979. Oxygen isotope analysis of Antarctic snow and ice. (M.Sc thesis, University of Melbourne.)

Morgan, V. I., C.W. Wookey, Li Jun, T. D. van Ommen, W. Skinner and M. F. Fitzpatrick. 1997. Site information and initial results from dccp drilling on Law Dome, Antarctica. J. Glaciol., 43 (143), 3-10

Neftel, A., P. Jacob and D. Klockow. 1986. Long term record of $\mathrm{H}_{2} \mathrm{O}_{2}$ in polar ice cores. Tellus, 38B $34,262270$.

Neftel, A., R. C. Bales and D. J. Jacob. 1995. $\mathrm{H}_{2} \mathrm{O}_{2}$ and $\mathrm{HCHO}$ in polar snow and their relation to atmospheric chemistry. In Delmas, R. J., ed Ice core studies of global biogeochemical cycles. Berlin, etc., Springer-Verlagr 249-264. (NATO ASI Series I: Global Environmental Change 30.)

Paterson, W. S. B. 1994. The physics of glaciers. Third edition. Oxford, etc., Elsevier.

Raynaud, D. and B. Lcbel. 1979. Total gas content and surface elevation of polar ice sheets. Nature, 281(5729), 289-291.

Raynaud, D. and C. Lorius. 1973. Climatic implications of total gas content in ice at Camp Century. Nalure, 243(5405), 283-284.

Raynaud, D. and C. Lorius. 1977. Total gas content in polar ice: rheological and climatic implications. International Assaciation of Hydrological Sciences Publication 118 Symposium at Grenoble 1975 - Isolupes and Imparities in Snow and lce), $326-335$.

Raynaud, 1). and I. M. Whillans. 198?. Air content of the Byrd core and past changes in the West Antarctic ice sheet. Ann. Glaciol, 3, 269273.

Raynaud, D., J. Chappcllaz, C. Ritz and P. Martinerie. 1997. Air content along the Greenland Ice Core Project core: a record of surface climatic parameters and elevation in central Greenland. F. Geophys. Res., 102 (C12) $26,607-26,613$

Russcll-Hcad, D. S. and I. Simmonds. 1993. Temporal structure of surface weathe parameters at Casey, Dazis, Mawson and Macquarie Istand. Melbourne, University of Melbourne. Department of Meteorology. (Report No. 35.)

Saltiknv, S. 1976. Stereographic metallography. Moscow, Metallurgy Press.

Schwander, J. and B. Staulfer. 1984. Age difference between polar ice and the air trapped in its bubbles. Nature, 311 (5981; 45-47.

Stauffer, B., J. Schwander and H. Ocschgcr. 1985. Enclosure of air during metamorphosis of dry firn to ice. Ann. Glaciol., 6, 108-112.

Van Ommen, T. D. and V. Morgan. 1996 . Peroxide concentrations in the Dome Summit South ice core, Law Dome, Antarctica. 7. Geophys. Res. $101(1) 10 ; 15,147-15,152$

Van Ommen. T.D. and V. Morgan. 1997. Calibrating the ice core paleothermometer using seasonality. J. Geophys. Res., 102 (D8), 9351-9357.

Whillans, I. M. 1981. Reaction of the accumulation zone portions of glacicrs to climatic change. 7. Geophys. Res, 86 (C5), 4274-4282.

Xie, Z., J. Li and N.W. Young. 1989. Physical characteristics of the snow and ice cover of Law Dorne, East Antarctica. In Chinese Committee on Antarctic Research. Proceedings of the International Symposium on Antarctic Research, Hangzhou, China. Beijing, China Ocean Press, 822 